\title{
THE AGQUIRING OF THE KNOWLEDGE ABOUT STANDARDS IN THE DIGITAL ERA
}

\author{
Ivana Mijatović ${ }^{1 *}$, Biljana Tošić ${ }^{2}$ and Milan Jovanović ${ }^{3}$ \\ ${ }^{1223)}$ Faculty of Organizational Sciences, University of Belgrade, Serbia
}

Please cite this article as:

Mijatović, I., Tošić, B. and Jovanović, M., 2019. The

Acquiring of the Knowledge about Standards in the

Digital Era. Amfiteatru Economic, 21(51), pp. 427-441.

\section{Article History}

Received: 10 October 2018

Revised: 1 February 2019

Accepted: 20 March 2019

DOI: $10.24818 / \mathrm{EA} / 2019 / 51 / 427$

\begin{abstract}
The knowledge from external sources has been recognized as critical for improving the capabilities of small and medium enterprises (SMEs) to be competitive on the global market. The aim of this paper is to explore main factors which affect SMEs' choice of a dominant source for acquiring information and the knowledge about standards. The questionnaire survey research method was used to seek the response from representatives of 130 SMEs operating in Serbia. Our findings indicate four sources - relevant websites, services of consultants, inputs of customers as well as information received from business partners. Our results showed that larger SMEs, with a longer tradition in business, will have more chances to use Websites as a primary source for gaining knowledge about standards. Domestic SMEs shape their decisions to hire consultants predominantly because of a negative perception of standards. The usage of customer inputs as a dominant source for gaining information and transfer of knowledge about standards are influenced by SMEs' experience in business and negative perception of the benefits of standards. In the digital era, SMEs still suffer from a lack of resources or capabilities to use the Web and the Internet for acquiring information and knowledge about standards in the digital era.
\end{abstract}

Keywords: standards, SMEs, certification, knowledge, digital era.

JEL Classification: D83, L15, L25, O33.

* Corresponding author, Ivana Mijatović - ivanamt@ fon.bg.ac.rs 


\section{Introduction}

Capabilities of SMEs, to be competitive on the global market in a knowledge-driven economy, are high in agendas of many actors - governments, international organizations, chambers of commerce, professional organizations as well as industry associations. SMEs have to be at the centre of microeconomic competitiveness strategies - as they are dominant job creators on the global market (Haltiwanger et al., 2013). In the European Union, 99.8\% of all enterprises are SMEs and about 23 million SMEs provide around 75 million jobs accounting for $67 \%$ of total employment in the non-financial business sector (European Commission, 2016a). According to the Annual Report on European SMEs (European Commission, 2017), SMEs are a major source of entrepreneurial skills, innovation and employment. In Serbia, $99.4 \%$ of all enterprises are SMEs. SMEs in Serbia contribute a share of roughly $60 \%$ of employment and less than $50 \%$ of value added, compared with the respective EU averages of $67 \%$ and $57 \%$. Micro-firms make a particularly small contribution, providing only $10 \%$ of value added which is 11 percentage points lower than in the EU (European Commission, 2016b)

In emerging economies, a contribution of SMEs is to drive the development of a knowledge-driven economy, on the other side, in developed countries, SMEs support is seen as crucial for the recovery after the global financial crisis (Massaro et al., 2016). However, SMEs are most vulnerable to: lack of information, knowledge and incentive; skill shortages; limited market power; high dependence on partners; market behaviour of competitors and information asymmetry affects them in many ways (Arcuri and Levratto, 2018, Chong et al., 2011; La Rocca et al., 2011). In many cases, SMEs ability to acquire knowledge in the digital era is dominant prerequisite to develop and sustain competitive advantage on the global market.

More than ever before, global and regional initiatives for education about standardization are intensive and actual. The Joint Initiative on Standardization under the Single Market Strategy of European Commission, which started at June $13^{\text {th }} 2016$, gives high priority on education about standardization (Action 3) and position of SMEs in standardization in supporting European competitiveness in the global market. Knowledge about standardization is important because of the role of standards and standardization in global and knowledge-driven economy, especially for the less developed countries. The capability of SMEs to acquire the information and gain knowledge about standards and standardization in the digital era has become the dominant prerequisite to develop and sustain competitive advantage on the global market.

The aim of this study is to explore main factors which affect SMEs' choice of a dominant source for acquiring information and knowledge about standards in the digital era. Nowadays, in the socially networked society, it would be logical that main sources of information can be found on the Web and the Internet. However, information and knowledge about standards, standardization and other related activities might be quite specific. After the introduction, the study provides a review of the literature in order to explain the importance of knowledge transfer for SMEs, the role of standards and standardization at a global market, roles of certification in SMEs and. The second section is dedicated to the research methodology (research questions, study design, data analysis and study participants). The results with the summary statistics for Discriminant Function Analysis (DFA) follow. Finally, the study offers discussion and conclusion remarks, with suggestions for future research. 


\section{Literature review}

\subsection{Importance of knowledge transfers for SMEs}

Knowledge management practices in large companies are more elaborated in research studies then the same practice in SMEs (Massaro et al., 2018; Cantu et al., 2009; Pillania, 2006; Corso et al., 2003; Matlay et al., 2002; McAdam and Reid, 2001; Beijerse, 2000; Julien, 1993). The SMEs are generally constrained by limited resources employed (Chong et al., 2011), their management capabilities (Pillania, 2008) as well as the fact that large enterprises generally rely on systematic mechanisms to manage their knowledge-based resources (Cantu et al., 2009). Primarily, the studies related to knowledge management in SMEs are concentrated on the acquisition and use of knowledge, treating it as an asset that is transferred by routines (Pittaway, 2005). Although large enterprises have led the way in introducing and implementing various knowledge management initiatives (Wong, 2005), there is a belief that today's SMEs should also invent and implement such practices in order to enhance their competitiveness (Cantu et al., 2009).

The majority of prior studies of knowledge transfer refer to knowledge typologies that distinguish between external and internal organizational knowledge (De Zubielqui et al., 2018). While external knowledge may present knowledge transferred through collaborative arrangements, relationships networks, alliances and other different forms of interaction with external sources of knowledge (Lasagni, 2012), the internal transfer of knowledge includes collaboration across formal organizational boundaries within and across SMEs (Chong et al., 2011). The external transfer of knowledge has been recognized as critical to the competitiveness of SMEs in view of their resource limitations (Chong et al., 2011) as well as key drivers of SMEs innovation (Lasagni, 2012).

External knowledge is generally believed to be of major importance to SMEs (Chen et al., 2006) which is why the internal knowledge management issues in these enterprises may thus not be sufficiently taken into account. Indeed, "collaborating with external actors provides SMEs with greater access to a wider pool of knowledge, technologies and other external resources" (De Zubielqui et al., 2018). It is for these reasons that the integration of external knowledge from customer involvement and internal knowledge transfer into already existing systems and structures has become a new paradigm for organizational knowledge. It assumes that SMEs can and should use external sources as well as internal sources and internal and external paths to market (Chesbrough, 2006) as they look to advance their innovations, enhance core business performance and improve their competitiveness.

The rationale for SMEs adopting the concept of knowledge management is predominately linked to their learning orientation which refers to the "organization-wide activity of creating and using knowledge to enhance their competitive advantage" (Calantone et al., 2002). According to the same authors, learning orientation includes the commitment to learning, shared vision, open-mindedness, inter-organizational knowledge sharing as well as firm innovativeness (Calantone et al., 2002).

Many academics and practitioners have been examining the relationship between knowledge transfer (Liu et al., 2017; De Zubielqui et al., 2018), innovation (Malerba and McKelvey, 2018) and firm performance (Leitner and Guldenberg, 2010; Han et al., 2016; De Zubielqui et al., 2017). Whilst some authors explored the knowledge acquisition process of innovative SMEs in the context of geographic proximity to similar firms and canters of 
research excellence (Davenport, 2005), to date, the focus has mainly been up to the open innovation practices and their effect on acquiring knowledge at innovative SMEs (Chesbrough, 2006; Elmquist et al., 2009; Gassmann et al., 2010; Ebersberger et al., 2012; Hewitt-Dundas \& Roper, 2018).

In line with these challenges, the study of Martin-Rios and Erhardt (2017) explored strategies for acquiring knowledge in technology-innovative SMEs and the role that informal and proximate relationships play in the development of knowledge networks through which knowledge transfer occurs. This seems to indicate that SMEs engagement in the exchange of various sources of knowledge is directly related to its economic activity and strategic knowledge priorities which shape the structural dimension of inter-organizational informal networks (Martin-Rios and Erhardt, 2017). It is important to balance the exploitation of existing knowledge with an exploration for the new knowledge as both strategies are valuable and can gain the competitive advantage (Pollard and Svarcova, 2009).

Ratnawati et al. (2018) summarize that SMEs cannot achieve competitive advantage if they only prioritize their own tangible assets, without seeking for the effort in acquiring knowledge. Due to resource constraints, SMEs usually tend to be more creative in working around these challenges in order to develop adequate knowledge management strategies (Desouza and Awazy, 2006). Study of Sparrow (2005) related to different approaches towards the development of knowledge management strategies within SMEs showed that different groups of SMEs approach knowledge management in fundamentally different ways.

The strategies for acquiring knowledge in technology-innovative SMEs have been particularly emphasized by Whittaker et al. (2016), according to whom SMEs can benefit from different capability strategies depending on their age. According to these authors, accessing external resources for younger SMEs can have a positive effect, while older SMEs can benefit from a combined strategy. Same study findings indicate that demographic characteristics of the owner and/or manager can influence the capability assembling strategy and are, therefore, an important contingency for the innovation performance of SMEs (Whittaker et al., 2016). Furthermore, the study of Han et al. (2016) explored the influence of the knowledge transfer on subsequent innovation performance and the results showed that a high quality of overlapped knowledge has a positive effect on subsequent innovation performance, while the effect is negative for non-overlapped knowledge quality.

According to the experience of South Korea, the study of Rhee et al. (2009) showed that a continued commitment to learning is central to innovativeness and performance in technology-innovative small firms. The findings imply that market orientation and entrepreneurial orientation significantly influences learning orientation, respectively. Additionally, managers with entrepreneurial orientation and market orientation should place much emphasis on learning orientation in order to boost innovativeness and ultimately achieve performance (Rhee et al. 2009). These claims were supported by Study of Messeghem (2003) on 'corporate entrepreneurship' showed that SMEs, in the process of building up a framework for their learning activities, can still follow an entrepreneurial orientation. Similar results can be founded in the empirical analysis of Lasagni (2012), based on data collected from 500 European SMEs, which indicate that innovation performance is higher in SMEs that are proactive in strengthening their relationship with innovative suppliers, users and customers. Considering that innovativeness is a key factor in SMEs competitiveness in today's globally competitive marketplace, knowledge transfer 
is definitely being recognized as the most valuable asset these enterprises can use to innovate their business as well as improve their performance (Ussman et al., 2001; Smith and Webster, 2000).

\subsection{Roles of standards and standardization at a global market}

Standards can take various shapes and can be developed by governments, formal organizations for standardisation (e.g. international, regional or national), professional or industry associations, business associations and consortia as well as by companies. The proliferation of standards by many actors that develop or participate in developments of standards, different ways or mechanism for developments of standards, possibilities for global companies to develop standards in different frames and organizations, in accordance of their preferences (forum shopping) substantially changed the business experience one company may have on any market. Standards are dealing on predominately technical issues, however, their influences are mainly economic - standards can help or hinder companies' efforts to enter on specific markets (Hesser and Czaya, 2007).

Even those it depends on nature of standards, the interrelation between standards and economic performances on micro and macro levels (e.g. technological change, competition and international trade and other) are evident (Pham, 2007; Blind, 2004). A market for products and services is, in many ways, connected to "crystallization of regulation, technical standards, certification, accreditation into granting - or not granting - a product the right to enter to specific market" (Frankel and Galland, 2015).

There has been an extensive literature on the rise of global standards (Androniceanu and Drăgulănescu, 2012; Barretta-Herman, 2008; Angel and Rock, 2005; Ponte and Gibbon, 2005; Dowell et al., 2000). The focus has mainly been on the management system standards and the governance of global value chains (Popa, 2013; Renard, 2003; Ponte and Gibbon, 2005); pragmatic emergence of Standards Development Organizations (SDOs) (Loconto and Busch, 2010; Murphy and Yates, 2009) as well as the international trade, techno-economic networks and global market economy (Renard, 2005; Dowel et al., 2000 Gereffi, 1999). Evidently, the literature strongly suggests the role of standards in governing the global economy (Nadvi and Wältring, 2002; Ponte and Gibbon, 2005; Loconto and of Busch, 2010). While the focus has often been on the generic social, environmental and quality standards, Coe and Hess (2007), point out that "equal emphasis has to be put on the networks generating technological (industry) standards".

According to Ponte and Gibbon (2005), the role of global standards in shaping access to international trade should be understood in relation to the changing features of consumption in industrialized economies. In a situation where customers and end-users evidently seek value in their daily purchases, standards are often seen as a commonly accepted base for preventing information asymmetry - the fact that producers have much more information about their products than customers (Mahmoud et al., 2017; Nadvi, 2008).

The popular myths that standards are applicable only to large enterprises, that implementation of standards can cause high expenses and that SMEs cannot benefit from standardization itself need to be busted (BSI, 2018). Having in mind that standards have a considerable impact on governance structures in value chains and production networks (Coe et al., 2008), global companies have become major players on the world stage (Dowell et al., 2000) and positions of SMEs are particularly complex. For SMEs understanding arena of standardization and learning how to benefit from the usage of 
standards are prerequisite for competitiveness even on local markets. A variety of interests of SMEs in standardization are still not clearly explained.

Given their economic relevance, the ability of SMEs to acquire knowledge about standards and become competitive in the global market is essential for economic development (La Rocca et al., 2011). Therefore, in the situation where most organizations are experiencing changes in the global competitive marketplace, there is no longer a question if these enterprises should participate in the standardization process, but what is the most effective way to do that.

\subsection{Role of certification in SMEs}

Internationalization has become a cornerstone of competitiveness (Park et al., 2015) and "the world economy is becoming increasingly integrated with continued declines in government-imposed barriers and continued advances in technology" (Lu and Beamish, 2001). Most SMEs are faced with international competition even on domestic markets, and they need the tool to add credibility. According to ISO (2018) certification can be seen as a useful tool to add credibility, by demonstrating that product, process, system or person meets the expectations. Certification is the provision by an independent body of written assurance (a certificate) that the product, service or system in question meets specific requirements (ISO, 2018). In many cases, specific requirements are defined by standards.

Certification of SMEs is most apparent in the area of quality assurance, with the dominance of certification in accordance with the standard ISO 9001. Quality certification itself focuses on the organization's provision of competent staffing which includes providing continuing educational opportunities and knowledge transfer within the organization (Gingerich, 2007). Several studies showed that external market-based factors (market growth and diversification), knowledge-sharing and interest representation are main motivators for certification (Melewar et al., 2008; Fransen and Kolk, 2007; Renard, 2005). On the other side, the survey conducted by Heras-Saizarbitoria and Boiral (2013) indicate that organizations tend to adopt ISO 9001 symbolically in response to various interorganizational contingencies rather than as part of their adaptation to external pressures. Sitki Ilkay and Aslan (2012) found out that SMEs that are internally motivated for certification have partially higher performance than organizations externally motivated. The obstacles for the ISO 9001 certification in SMEs can be summarized as: high implementation costs, inadequate resources and insufficient external assistance Lo and Humphreys (2000).

Results of empirical studies related to the effects of quality certification are different. Li et al. (2018) argued about the effects of certification on reputation. The study of Rillo and Mijatovic (2016) highlighted the fact that quality certification is more important to the organizations from developing countries as it is connected with "building of reputation". Study of Sadiq Sohail and Boon Hoong (2003) indicate that there are significant differences in performances between certified and non-certified organizations, supporting the hypothesis that ISO 9001 certification contributes to a higher organizational performance. Terziovski and Power (2007) suggest that organizations that seek ISO 9001 certification with a proactive approach driven by a continuous improvement strategy are more likely to derive significant business benefits as a result. The same authors note that "organizations can effectively use the quality certification as a means of promoting and facilitating a 
quality culture, where the quality auditor is an important player in the process" (Terziovski and Power, 2007).

However, Rahman (2001) found out that there was no statistically significant difference between SMEs, with and without ISO 9001 certificate, with respect to the Total Quality Management (TQM) implementation and organizational performance. Sun and Cheng (2002) highlighted the fact that there is no significant correlation between the current ISO 9001 certification and improvement of business performance. Moreover, their key findings indicate that SMEs implement global standards and TQM practices mainly because of market requirements or external pressure rather than inter-organizational initiative (Sun and Cheng, 2002).

\subsection{Research questions}

Based on literature review, as the knowledge transfer from external sources and external knowledge for SMEs has important implications for outcomes of SMEs, the information and knowledge about standardization are important prerequisites for competitiveness on even local markets, it would be important to more clearly understand what are the influences on SMEs decision to choose the dominant source for information and knowledge about standards. The research questions presented in this paper were driven by four main research questions (RQs):

RQ 1: What are the main predictors of the usage-relevant Web sites as a dominant source for information and knowledge about standards in the case of SMEs operating in Serbia?

RQ 2: What are the main predictors of the user services of consultants as a dominant source for information and knowledge about standards in the case of SMEs operating in Serbia?

RQ 3: What are the main predictors of the consumers as a dominant source for information and knowledge about standards in the case of SMEs operating in Serbia?

RQ 4: What are the main predictors of partners and others as a dominant source for information and knowledge about standards in the case of SMEs operating in Serbia?

\section{Research methodology}

\subsection{Study design}

In order to find answers to our research questions, a questionnaire survey research method was used to seek the response from representatives of SMEs that operate in Serbia. We used several sources for reaching representatives of SMEs - database of companies of the Chamber of Commerce of Republic of Serbia (publicly available contact with basic information on the website of Chamber of Commerce), LinkedIn profiles of companies and direct e-mail contacts. In order to receive as many responses as possible, we created a relatively short and compact questionnaire, taking into account the recommendation for defining a questionnaire and a survey design of Czaja and Blair (2005). In order to find out what influences the choice of SMEs operating in Serbia, to use predominantly one source for seeking the information and the knowledge about standards, examinees are asked to choose only one dominant source for gaining knowledge. We observed four sources relevant Websites, services of consultants, customers and business and other partners (dependent variables is coded as dummy variables: use $=1$ and no use $=0$ ) 


\subsection{Data analysis}

For the data analysis and answering our RQs we used descriptive statistics and we conducted a two-group Discriminant Function Analysis (DFA) based on the Wilks' lambda. Interpretation of the DFA is based on discriminant loading because it is less affected by multi co-linearity and more suitable for interpretation in explorative research (Hair et al., 2009). According to the same author, discriminate loadings above \pm 0.40 should be used to identify substantive discriminant (independent) variables even when they are not included in DFA analysis. The Canonical Correlation (CC) coefficient is used to define the percentage of variance in the dependent variable explained by the mutual influence of independent variables. Based on the study of Harlow (2005), the substantial value of canonical correlation is 0.30 or higher, for example, the value of 0.30 corresponding to about $10 \%$ of the variance explained.

\subsection{Study participants}

Questionnaires were sent via LinkedIn and E-mail to 540 companies and we received 143 responds (26.5\%), 13 questionnaires being invalid for the reason of not being SMEs or incomplete data and a total of 130 or $24 \%$ questionnaires have been taken into account. Characteristics of the responding companies are presented in table no. 1.

Table no. 1: Characteristics of responding SMEs

\begin{tabular}{|c|c|c|c|c|c|c|c|c|c|c|}
\hline & \multicolumn{2}{|c|}{ Total } & \multicolumn{4}{|c|}{ Ownership } & \multicolumn{4}{|c|}{ Ownership2 } \\
\hline & \multirow{2}{*}{ No. } & \multirow{2}{*}{$\%$} & \multicolumn{2}{|c|}{ Public } & \multicolumn{2}{|c|}{ Private } & \multicolumn{2}{|c|}{ Foreign } & \multicolumn{2}{|c|}{ Domestic } \\
\hline & & & No. & $\%$ & No. & $\%$ & No. & $\%$ & No. & $\%$ \\
\hline & 130 & 100 & 10 & 7.7 & 120 & 92.3 & 30 & 23.1 & 100 & 76.9 \\
\hline \multicolumn{11}{|c|}{ Industry } \\
\hline Manufacturing & 31 & 23.8 & 2 & 6.5 & 29 & 93.5 & 10 & 32.3 & 21 & 67.7 \\
\hline Service & 72 & 55.4 & 8 & 11.1 & 64 & 88.9 & 18 & 25 & 54 & 75 \\
\hline Trade & 22 & 16.9 & 0 & 0 & 22 & 100 & 1 & 4.5 & 21 & 95.5 \\
\hline Other & 5 & 3.8 & 0 & 0 & 5 & 100 & 1 & 20 & 4 & 80 \\
\hline \multicolumn{11}{|c|}{ Number of employees } \\
\hline 0-10 & 49 & 37.7 & 1 & 2 & 48 & 90 & 1 & 2 & 48 & 98 \\
\hline $11-50$ & 41 & 31.5 & 1 & 2.4 & 40 & 97.6 & 9 & 22 & 32 & 78 \\
\hline 50-250 & 40 & 30.8 & 8 & 20 & 32 & 80 & 20 & 50 & 20 & 50 \\
\hline \multicolumn{11}{|c|}{ Experience in the certification of processes or products } \\
\hline $\begin{array}{l}\text { Experience in } \\
\text { the } \\
\text { certification of } \\
\text { processes and } \\
\text { products }\end{array}$ & 42 & 32.3 & 6 & 14.3 & 36 & 85.7 & 14 & 33.3 & 28 & 66.7 \\
\hline $\begin{array}{l}\text { Experience in } \\
\text { certification } \\
\text { with process or } \\
\text { products }\end{array}$ & 27 & 20.8 & 1 & 3.7 & 26 & 96.3 & 6 & 22.2 & 21 & 77.8 \\
\hline $\begin{array}{l}\text { No experience } \\
\text { in certification }\end{array}$ & 61 & 46.9 & 3 & 4.9 & 58 & 95.1 & 10 & 16.4 & 51 & 51 \\
\hline
\end{tabular}




\section{Results and discussion}

In order to analyze the reliability of observed items, we used the reliability coefficient of Cronbach's alpha. According to Hair et al. (2009), the lower limit for Cronbach's alpha is 0.70 , although it may also be decreased to 0.60 in exploratory research. The reliability analysis showed an adequate consistency of the entire scale, wherein it is possible to form a summated scale for: 1) perceived benefits from certification $(\alpha=0.807)$ and 2) perceived reputation benefits of application of standards $(\alpha=0.738)$.

- RQ 1: What are the main predictors of the usage of relevant Web sites as a dominant source for information and knowledge about standards in the case of SMEs operating in Serbia?

The dominant variable that influences usage of Websites at observed SMEs, as the dominant source for gaining information and transfer of knowledge about standards, is a number of employees (table no. 2). Only variable x2: Experience in business (years) have discriminant loadings higher than $0.4(0.43)$ and can be discussed in this result. The larger SMEs with the longer tradition in business will have more chances to use Websites as a primary source for gaining knowledge about standards. Values of squared canonical correlations suggested that influence of the number of employees is positive and significant, but it corresponded only about $4 \%$ to variation between SMEs that use Websites and SMEs that do not use Web Sites as the dominant source of knowledge about standards.

Table no. 2: Summary Statistics for Discriminant Function Analysis

\begin{tabular}{|l|c|c|c|c|c|c|c|c|c|c|c|c|}
\hline \multirow{2}{*}{$\begin{array}{c}\text { Dependent } \\
\text { variable }\end{array}$} & \multirow{2}{*}{$\begin{array}{c}\text { Wilks' } \\
\text { Lambda }\end{array}$} & \multirow{2}{*}{$\mathbf{p}$} & \multicolumn{6}{|c|}{ Discriminant loadings (structure correlations) } & \multirow{2}{*}{ CC } \\
\cline { 4 - 13 } & & & $\mathrm{X} 1$ & $\mathrm{X} 2$ & $\mathrm{X} 3$ & $\mathrm{X} 4$ & $\mathrm{X} 5$ & $\mathrm{X} 6$ & $\mathrm{X} 7$ & $\mathrm{X} 8$ & $\mathrm{X} 9$ & \\
\hline Websites & 0.967 & 0.04 & $\mathbf{1 . 0 0}$ & $\mathbf{0 . 4 3}$ & 0.28 & 0.11 & 0.12 & -0.38 & -0.27 & 0.23 & 0.09 & 0.18 \\
\hline Consultants & 0.909 & 0.02 & -0.34 & -0.06 & -0.20 & $\mathbf{- 0 . 5 2}$ & $\mathbf{- 0 . 7 0}$ & $\mathbf{0 . 7 1}$ & -0.07 & -0.21 & 0.19 & 0.34 \\
\hline Customers & 0.924 & 0.01 & 0.19 & $\mathbf{0 . 7 0}$ & 0.10 & $\mathbf{- 0 . 4 4}$ & $\mathbf{- 0 . 6 2}$ & 0.04 & -0.30 & -0.11 & -0.02 & 0.28 \\
\hline
\end{tabular}

Note: Legend: $\mathrm{x} 1$ - Number of employees; $\mathrm{x} 2$ - Experience in business (years); $\mathrm{x} 3$ - Experience with certification of processes or products; $\mathrm{x} 4$ - Perceived benefits from certifications; $\mathrm{x} 5$ - Perceived benefits from standards; $x 6$ - Domestic or foreign ownership; 7 - Public or private ownership; $\mathrm{x} 8$ - Industry (manufacturing or service and others) and $\mathrm{x} 9$ - Connections with other SMEs in same industry.

- RQ 2: What are the main predictors of the usage services of consultants as a dominant source for information and knowledge about standards in the case of SMEs operating in Serbia?

Variables that have a statistically significant influence on the usage of consultants' services as a dominant source for gaining information and transfer of knowledge about standards are the negative perception of standard and domestic ownership (table no. 2). The variable that has discriminant loadings higher than 0.4 , but is not included in function, is the negative perception of benefits of certifications. Those results suggest that domestic SMEs shape their decisions to hire consultants (use their services) predominantly because of their negative perception of standards and standardization. Values of squared canonical correlations suggested that the influence of the negative perception of benefits from standards and domestic ownership is significant, but it corresponded only about $12 \%$ to 
variation between SMEs that hire consultants and SMEs that do not use services of consultants for the purpose of gaining knowledge about standards.

- RQ 3: What are the main predictors of the consumers as a dominant source for information and knowledge about standards in the case of SMEs operating in Serbia?

Variables that have the statistically significant influence on the usage of customer inputs as the dominant source for gaining information and transfer of knowledge about standards are experiencing in business (years) and negative perception of benefits of standards (Table 2). The negative perception of certifications has discriminant loadings higher than $0.4(-0.44)$. Those results suggest that domestic SMEs are pressured by their B2B customers, trough requirements for standards adoption and second part certifications but SMEs have a negative perception of standards and certification. Values of squared canonical correlations suggested that influence of experience in business, negative perception of benefits from standards and domestic ownership are significant, but it corresponded only about $9 \%$ to variation between SMEs that see customers and SMEs that do not see customers as the dominant source for gaining information and knowledge about standards.

- RQ 4: What are the main predictors of partners and others as a dominant source for information and knowledge about standards in the case of SMEs operating in Serbia?

Our data analysis failed to find any statistically significant influence of observed dependent variables on the choice of observed SMEs to have business partners and other partners as a dominant source for information and gaining knowledge about standards.

\section{Conclusions}

The main intention in this article was to explore key factors which affect SMEs' choice of a dominant source for acquiring the information and the knowledge about standards. In the digital era, SMEs still suffer from a lack of resources or capabilities to use the WEB and the Internet for acquiring information and knowledge about standards. Our results showed that observed SMEs operating in Serbia use Websites as the main source for acquiring information and knowledge only if they are larger (medium) and more experienced. In the broader sense, our results agree with findings of the study of Neirotti et al. (2018) that adoption of Information and Communication Technology (ICT) in SMEs "has some peculiarities that may depend on the combined effect of size and competitive environment" and that ICT-based capabilities are more diffused among larger SMEs.

Our results showed that domestic SMEs, due negative perception about standards, use services of consultants for the purpose of gaining knowledge about standards. Two problems that have roots in the negative perception of standards are already visible in practice - the inability of domestic SMEs for successful technological catch-up and lowering quality and effects of consultants' work. Those results might indicate, that SMEs' negative perception toward standards and standardization and finding "easy-way" to fulfil minimum requirements of standards by hiring consultants, lead to the absence of learning orientation and balance the exploitation of existing knowledge with an exploration for the new knowledge (Pollard and Svarcova, 2009). Even though SMEs need to apply standards and benefit from certification, the knowledge about how to use standards and benefit from their use often is not transferred adequately from consultants to SMEs. 
However, our research results suggest that more attention should be paid to improve the capabilities of SMEs for more active use of digital technologies in order to acquire the knowledge about standards, standardization and related activities. On the other side, the task of many actors: governments, universities, organizations for standardization, consultants and others is to explore why SMEs are missing the chance to benefit from the implementation of standards due to their lack of abilities to use technology-enhanced learning in a digital era. In a knowledge-driven economy, it is important to explore knowledge transfers from supply chain actors, influences of knowledge transfer on performances of companies as well as how knowledge quality also influences these relationships. Our next researches will be dedicated to these issues.

\section{References}

Androniceanu, A. and Drăgulănescu, I.V., 2012. Sustainability of the organizational changes in the context of global economic crisis. Amfiteatru Economic, 14(32), pp.365-379.

Angel, D.P. and Rock, M.T., 2005. Global standards and the environmental performance of industry. Environment and Planning, 37(11), pp.1903-1918.

Arcuri, G. and Levratto, N., 2018. Early stage SME bankruptcy: does the local banking market matter?. Small Business Economics, pp.1-16. doi.org/10.1007/s11187-0180042-4.

Barretta-Herman, A., 2008. Meeting the expectations of the Global Standards: A status report on the IASSW membership. International Social Work, 51(6), pp.823-834.

Beijerse, R.P., 2000. Knowledge management in small and medium-sized companies: knowledge management for entrepreneurs. Journal of knowledge management, 4(2), pp.162-179.

Blind, K., 2004. The economics of standards: theory, evidence and practice. Cheltenham: Edward Elgar Publishing.

BSI, 2018. Standards and small business. [online] Available at: <https://www.bsigroup. com/en-GB/standards/who-uses-standards/standards-and-small-business/> [Accessed 8 March 2018].

Calantone, R.J., Cavusgil, S.T. and Zhao, Y., 2002. Learning orientation, firm innovation capability, and firm performance. Industrial marketing management, 31(6), pp.515-524.

Cantú, L., Rialp Criado, J. and Rialp Criado, A., 2009. Generation and transfer of knowledge in IT-related SMEs. Journal of knowledge management, 13(5), pp.243-256.

Chen, S., Duan, Y., Edwards, J.S. and Lehaney, B., 2006. Toward understanding interorganizational knowledge transfer needs in SMEs: insight from a UK investigation. Journal of knowledge management, 10(3), pp.6-23.

Chesbrough, H.W., 2006. Open innovation: The new imperative for creating and profiting from technology. Cambridge: Harvard Business Press.

Chong, C., Choy Chong, S. and Chew Gan, G., 2011. Inter-organizational knowledge transfer needs among small and medium enterprises. Library Review, 60(1), pp.37-52.

Coe, N., Dicken, P. and Hess, M., 2008. Introduction: Global production networks - debates and challenges. Journal of Economic Geography, 8(3), pp.267-269. 
Corso, M., Martini, A., Pellegrini, L. and Paolucci, E., 2003. Technological and organizational tools for knowledge management: in search of configurations. Small business economics, 21(4), pp.397-408.

Czaja, R. and Blair, J., 2005. Designing Surveys-A Guide to Decisions and Procedures Pine. Thousand Oaks: Forge Press.

Davenport, S., 2005. Exploring the role of proximity in SME knowledge-acquisition. Research policy, 34(5), pp.683-701.

De Zubielqui, G.C., Fryges, H. and Jones, J., 2017. Social media, open innovation \& HRM: implications for performance. Technological Forecasting and Social Change, 5, pp.114.

De Zubielqui, G.C., Lindsay, N., Lindsay, W. and Jones, J., 2018. Knowledge quality, innovation and firm performance: a study of knowledge transfer in SMEs. Small Business Economics, pp.1-20. doi.org/10.1007/s11187-018-0046-0.

Desouza, K.C. and Awazu, Y., 2006. Knowledge management at SMEs: five peculiarities. Journal of knowledge management, 10(1), pp.32-43.

Dowell, G., Hart, S. and Yeung, B., 2000. Do corporate global environmental standards create or destroy market value?. Management science, 46(8), pp.1059-1074.

Ebersberger, B., Bloch, C., Herstad, S.J. and Van De Velde, E.L.S., 2012. Open innovation practices and their effect on innovation performance. International Journal of Innovation and Technology Management, 9(06), p.1250040.

Elmquist, M., Fredberg, T. and Ollila, S., 2009. Exploring the field of open innovation. European Journal of Innovation Management, 12(3), pp.326-345.

European Commission, 2016a. Definition of Small and Medium-Sized Enterprises (SMEs). [online] Available at: <http://ec.europa.eu/growth/smes/business-friendlyenvironment/sme-definition_en> [Accessed 8 March 2018].

European Commission, 2016b. SBA Fact Sheet Serbia. [online] Available at: $<$ https://ec.europa.eu/docsroom/documents/22382> [Accessed 18 March 2018].

European Commission, 2017. Annual Report on European SMEs. [online] Available at <http://ec.europa.eu/growth/smes/business-friendly-environment/performance-review> [Accessed 8 March 2018].

Frankel, C. and Galland, J.P., 2015. Market, Regulation. In: K.B. Skriver, K. Jakobs and J. Jerlang, (2015 ed.) EURAS Proceedings - The Role of Standards in Transatlantic Trade and Regulation. Aachen: Verlaghaus Mainz GmbH.

Fransen, L.W. and Kolk, A., 2007. Global rule-setting for business: A critical analysis of multi-stakeholder standards. Organization, 14(5), pp.667-684.

Gassmann, O., Enkel, E. and Chesbrough, H., 2010. The future of open innovation. $R \& D$ Management, 40(3), pp.213-221.

Gereffi, G., 1999. International trade and industrial upgrading in the apparel commodity chain. Journal of International Economics, 48(1), pp.37-70.

Gingerich, B.S., 2007. Accreditation, certification and licensing actions certification standards. Home Health Care Management \& Practice, 19(6), pp.482-484.

Hair, J.F., Black, W.C., Babin, B.J., Anderson, R.E. and Tatham, R.L., 2009. Análise multivariada de dados. Porto Alegre: Bookman. 
Haltiwanger, J., Jarmin, R.S. and Miranda, J., 2013. Who creates jobs? Small versus large versus young. Review of Economics and Statistics, 95(2), pp.347-361.

Han, J., Jo, G.S. and Kang, J., 2016. Is high-quality knowledge always beneficial? Knowledge overlap and innovation performance in technological mergers and acquisitions. Journal of Management \& Organization, 24(2), pp.1-21.

Harlow, L.L., 2014. The essence of multivariate thinking: Basic themes and methods. New York: Routledge.

Heras-Saizarbitoria, I. and Boiral, O., 2015. Symbolic adoption of ISO 9000 in small and medium-sized enterprises: The role of internal contingencies. International Small Business Journal, 33(3), pp.299-320.

Hesser, W. and Czaya, A., 2007. The Standardization Policy of European Union. In: W. Hesser, A. Feilzer, A. and H. de Vries (ed. 2007). Standardization in Companies and Markets. Hamburg: Helmut Schmidt University. pp 455.-511.

Hewitt-Dundas, N. and Roper, S., 2018. Exploring market failures in open innovation. International Small Business Journal, 36(1), pp.23-40.

ISO, 2018. The facts about certification. [online] Available at: <https://www.iso.org/certification.html> [Accessed 10 Octomber 2018].

Julien, P.A., 1993. Small businesses as a research subject: some reflections on knowledge of small businesses and its effects on economic theory. Small Business Economics, 5(2), pp.157-166.

La Rocca, M., La Rocca, T. and Cariola, A., 2011. Capital structure decisions during a firm's life cycle. Small Business Economics, 37(1), pp.107-130.

Lasagni, A., 2012. How can external relationships enhance innovation in SMEs? New evidence for Europe. Journal of Small Business Management, 50(2), pp.310-339.

Leitner, K.H. and Güldenberg, S., 2010. Generic strategies and firm performance in SMEs: a longitudinal study of Austrian SMEs. Small Business Economics, 35(2), pp.169-189.

Li, L., Chen, J., Gao, H. and Xie, L., 2018. The certification effect of government R\&D subsidies on innovative entrepreneurial firms' access to bank finance: evidence from China. Small Business Economics, 52(1), pp.241-249.

Liu, Y., Li, Y., Shi, L.H. and Liu, T., 2017. Knowledge transfer in buyer-supplier relationships: The role of transactional and relational governance mechanisms. Journal of Business Research, 78, pp.285-293.

Lo, V. and Humphreys, P., 2000. Project management benchmarks for SMEs implementing ISO 9000. Benchmarking: An International Journal, 7(4), pp.247-260.

Loconto, A. and Busch, L., 2010. Standards, techno-economic networks, and playing fields: Performing the global market economy. Review of International Political Economy, 17(3), pp.507-536.

Lu, J.W. and Beamish, P.W., 2001. The internationalization and performance of SMEs. Strategic Management Journal, 22(6-7), pp.565-586.

Mahmoud, M.A., Hinson, R.E. and Anim, P.A., 2018. Service innovation and customer satisfaction: the role of customer value creation. European Journal of Innovation Management, 21(3), pp.402-422.

Malerba, F. and McKelvey, M., 2018. Knowledge-intensive innovative entrepreneurship integrating Schumpeter, evolutionary economics, and innovation systems. Small Business Economics, 51(4), pp.1-20. 
Martin-Rios, C. and Erhardt, N., 2017. Small business activity and knowledge exchange in informal interfirm networks. International Small Business Journal, 35(3), pp.285-305.

Massaro, M., Handley, K., Bagnoli, C. and Dumay, J., 2016. Knowledge management in small and medium enterprises: a structured literature review. Journal of Knowledge Management, 20(2), pp.258-291.

Matlay, H., Mitra, J. and Barr, P., 2002. Managing learning, knowledge and innovation in SMEs: an empirical approach. Management Research News, 25(8/10), pp.126-128.

McAdam, R. and Reid, R., 2001. SME and large organisation perceptions of knowledge management: comparisons and contrasts. Journal of Knowledge Management, 5(3), pp.231-241.

Melewar, T.C., Hayday, D., Gupta, S. and Cohen, G., 2008. EU enlargement: a case study of branding standardisation. EuroMed Journal of Business, 3(2), pp.179-201.

Messeghem, K., 2003. Strategic entrepreneurship and managerial activities in SMEs. International Small Business Journal, 21(2), pp.197-212.

Murphy, C.N., Yates, J.A., 2009. The International Organization for Standardization (ISO): global governance through voluntary consensus. New York: Taylor \& Francis.

Nadvi, K. and Wältring, F., 2002. Making sense of global standards. In H. Schmitz (ed.), Local Enterprises in the Global Economy. Cheltenham: Edward Elgar.

Nadvi, K., 2008. Global standards, global governance and the organization of global value chains. Journal of Economic Geography, 8(3), pp.323-343.

Neirotti, P., Raguseo, E. and Paolucci, E., 2018. How SMEs develop ICT-based capabilities in response to their environment: Past evidence and implications for the uptake of the new ICT paradigm. Journal of Enterprise Information Management, 31(1), pp.10-37.

Park, S., LiPuma, J.A. and Prange, C., 2015. Venture capitalist and entrepreneur knowledge of new venture internationalization: A review of knowledge components. International Small Business Journal, 33(8), pp.901-928.

Pham, T.H., 2007. Economic Aspects of Standardization. In: W. Hesser, A. Feilzer and H. de Vries. Standardization in Companies and Markets. Hamburg: Helmut Schmidt University. pp.77-123.

Pillania, R.K., 2006. Leveraging knowledge for sustainable competitiveness in SMEs. International Journal of Globalisation and Small Business, 1(4), pp.393-406.

Pillania, R.K., 2008. Strategic issues in knowledge management in small and medium enterprises. Knowledge Management Research \& Practice, 6(4), pp.334-338.

Pittaway, L.A., Thorpe, R., Macpherson, A. and Holt, R., 2005. Using knowledge within small and medium-sized firms: A systematic review of the evidence. International Journal of Management Reviews, 7(4), pp.257-281.

Pollard, D. and Svarcova, J., 2009. Promoting knowledge transfer to Czech SMEs: the role of human resource development in increasing absorptive capacity. International Journal of Entrepreneurship and Small Business, 8(4), pp.499-515.

Ponte, S. and Gibbon, P., 2005. Quality standards, conventions and the governance of global value chains. Economy and Society, 34(1), pp.1-31.

Popa, V., 2013. The financial supply chain management: a new solution for supply chain resilience. Amfiteatru Economic, 15(33), pp.140-153. 
Rahman, S.U., 2001. A comparative study of TQM practice and organisational performance of SMEs with and without ISO 9000 certification. International Journal of Quality \& Reliability Management, 18(1), pp.35-49.

Ratnawati, Soetjipto, B.E., Murwani, F.D. and Wahyono, H., 2018. The Role of SMEs' Innovation and Learning Orientation in Mediating the Effect of CSR Programme on SMEs' Performance and Competitive Advantage. Global Business Review, 19(3 suppl), pp.21-38.

Renard, M.C., 2003. Fair trade: quality, market and conventions. Journal of Rural Studies, 19(1), pp.87-96.

Renard, M.C., 2005. Quality certification, regulation and power in fair trade. Journal Of Rural Studies, 21(4), pp.419-431.

Rhee, J., Park, T. and Lee, D.H., 2010. Drivers of innovativeness and performance for innovative SMEs in South Korea: Mediation of learning orientation. Technovation, 30(1), pp.65-75.

Rillo, C. and Mijatovic, I. 2016. Reputation gap and exports in developing countries: Does international quality certification matters. In: K. Jakobs, A. Mione, A.-F. CuttingDecelle, S. Mignon (ed. 2016). EURAS Proceedings 2016: Co-operation and Open Innovation. Mainz: Verlagsgruppe. pp.161-178.

Sadiq Sohail, M. and Boon Hoong, T., 2003. TQM practices and organizational performances of SMEs in Malaysia: Some empirical observations. Benchmarking: An International Journal, 10(1), pp.37-53.

Sitkı İlkay, M. and Aslan, E., 2012. The effect of the ISO 9001 quality management system on the performance of SMEs. International Journal of Quality \& Reliability Management, 29(7), pp.753-778.

Smith, J.M. and Webster, L., 2000. The Knowledge economy and SMEs: a survey of skills requirements. Business Information Review, 17(3), pp.138-146.

Sparrow, J., 2005. Classification of different knowledge management development approaches of SMEs. Knowledge Management Research \& Practice, 3(3), pp.136-145.

Sun, H. and Cheng, T.K., 2002. Comparing reasons, practices and effects of ISO 9000 certification and TQM implementation in Norwegian SMEs and large firms. International Small Business Journal, 20(4), pp.421-442.

Terziovski, M. and Power, D., 2007. Increasing ISO 9000 certification benefits: a continuous improvement approach. International Journal of Quality \& Reliability Management, 24(2), pp.141-163.

Ussman, A., Almeida, A., Ferreira, J., Mendes, L. and Franco, M., 2001. SMEs and innovation: Perceived barriers and behavioural patterns. The International Journal of Entrepreneurship and Innovation, 2(2), pp.111-118.

Whittaker, D.H., Fath, B.P. and Fiedler, A., 2016. Assembling capabilities for innovation: Evidence from new zealand SMEs. International Small Business Journal, 34(1), pp.123-143.

Wong, K., 2005. Critical success factors for implementing knowledge management in small and medium enterprises. Industrial Management \& Data Systems, 105(3), pp.261-279. 